Selcuk Journal of Agriculture and Food Sciences

http://sjafs.selcuk.edu.tr/sjafs/index

Research Article

\section{SJAFS}

(2021) 35 (2), 91-100

e-ISSN: $2458-8377$

DOI:10.15316/SJAFS.2021.234

\title{
The Response of Dry Bean to Water Stress at Various Growth Cycles in a Semi-Arid Region
}

iD Nurcan YAVUZ,"*

${ }^{1}$ Selçuk University, Faculty of Agriculture, Department of Farm Structures and Irrigation, Konya, Turkey

\begin{tabular}{l}
\hline ARTICLE INFO \\
\hline Article history: \\
Received date: 08.04 .2021 \\
Accepted date: 18.05 .2021 \\
\hline
\end{tabular}

Keywords:

Crop Coefficient

Crop Water Consumption

Seed Yield

Dry Beans

Yield Response Factor

\begin{abstract}
Poor irrigation management is resulted from some reasons such as lack of information relevant to the crop water use. That kind of information is necessarily prerequisites for both planners and producers to obtain irrigation program to minimize the yield losses under water stress conditions. A two-year, 2013-2014 growing season, field experiment was performed to determine the response of dry bean to the water deficiency in different growth stages at Konya plain of Turkey. The study was organized as randomized complete block design with three replications. Vegetative (V), reproductive (R), and pod filling-maturation $(\mathrm{P})$ three plant growth cycles as were examined with including rain-fed total eight irrigation treatments were researched. A 100\% crop water requirement (VRP) was considered full-irrigation treatment. Irrigation was not performed during vegetative, reproductive, and pod filling-maturation cycles or during a combination of those stages in other treatments. In results, depending on the irrigation treatments, actual evapotranspiration (ETa) for 2013 and 2014 varied from 104 to $544 \mathrm{~mm}$ and from 110 to $558 \mathrm{~mm}$, respectively.

The average crop coefficients $\left(K_{\mathrm{c}}\right)$ among the years were 0.75 for vegetative, 1.01 for reproductive, and 0.82 for pod filling-maturation stages. Depending on irrigation time, as decreasing the irrigation water resulted reducing seed yield. It was obvious that higher seed yield as well as yield components obtained full irrigation at entire growing season, which was preferable. An alternative to full irrigation in whole growth stages particularly in areas with insufficient water resources, performing full irrigation till initial of the filling-maturation cycle and then ending irrigation can be highly recommended as ideal, as it resulted water saving of $38 \%$, and rise $27 \%$ in irrigation water use efficiency (IWUE) as well as $20 \%$ seed yield loss by comparison to full irrigation.
\end{abstract}

\section{Introduction}

Water is increasingly being a scant tool in agriculture as the competitions between industrial, municipal, and environmental water utilizations is growing. In water shortage climates, possibly water availability is the vital important factor limiting growing of agriculture (Fernandez et al. 2002, Ferreira and Carr 2002, Deng et al. 2006, Zhou 2003). In such ecologies, inadequate irrigation practices is one of the main reasons affecting water scarcity increase since about more than $85 \%$ of available water has been used in irrigation (ErRaki et al. 2010). For contribution feed security, efficient water use as a consequently facilitation more lands under irrigation is necessarily prerequisites. Detail information relevant to the crop water consumption, critical crop growth cycles as well as correct irrigation program for maximum crop yield is very important role to play to design the water use of crop

\footnotetext{
* Corresponding author email: ncivicioglu@selcuk.edu.tr
}

production. Besides that, information about available water amount to meet the crop needs is also very important. Crop water sue differs through crop growing period due the variations in crop cover and climate conditions (Allen et al. 1998).

The focusing on $\mathrm{ET}_{\mathrm{a}}$ or total water consumption is the most fundamental issues for irrigation program. The field water budget is a well-known parameter considered to determine $\mathrm{ET}_{\mathrm{a}}$, that rises with and increasing the number of irrigation from one to several times. $K_{c}$, mainly varies by specific crop properties and less affected from clime, and $\mathrm{ET}_{\mathrm{o}}$ representing almost whole effects of weather are used also for calculation of $\mathrm{ET}_{\mathrm{a}}$ under stress conditions (Allen et al. 2005). Besides that, $K_{c}$ is also influenced from crop and water management as well as the characteristics of soil and irrigation system. The determination of $\mathrm{k}_{\mathrm{c}}$ under local environmental conditions is the back bone for improving the planning and success of irrigation management in various field crops (Kang et al. 2003). To estimate reference evapotranspiration $\left(\mathrm{ET}_{\mathrm{o}}\right)$, data obtained from Class A Pan are extensively used worldwide (Grismer 
et al 2002, Irmak et al 2002). However, a reliable estimation of $\mathrm{ET}_{\mathrm{o}}$ using pan evaporation $\left(\mathrm{E}_{\mathrm{pan}}\right)$ is necessarily perquisites for accurate determination of pan coefficients $\left(\mathrm{K}_{\mathrm{pan}}\right)$.

The Konya Plain having $8 \%$ of Turkey's arable lands with limited water resources has a semi-arid climate. Rainfall in the Konya Plain is none uniform and occurs around the winter months, hence limiting the preference of annual summer crops to very few. For crop production during this period irrigation is beneficial and most of the water used is obtained from groundwater reservoir. More than $75 \%$ of the total fresh water resources available for agricultural activities are used. For this reason, agro-research programs on water productivity and water conservation should be implemented in Konya plain (Yavuz et al. 2015). In Middle Anatolia Region, dry bean is considered one of the less water-consuming crops by comparison to the sugar beet, carrot, and corn plants.

Dry bean, growing worldwide, is rich supply of high-quality protein, and well-known top dry bean productions countries are Myanmar, India, Brazil, and China. In accordance of 2019 records, about $1 \%$ of the world production was obtained from Turkey (FAO 2020). In that production year, bean production was around 0.225 million ton under open field conditions (TUIK 2020). The share of Konya in production of Turkey was about $28 \%$ (0.06 million ton). It is impossible to obtain economical seed production without irrigation in both Konya plain and other parts of Turkey. Water scarcity and energy cost of water pumping during irrigation processes are two important reasons forced farmers to be shorten the irrigation number in Konya region. Those reasons have pushed producers as well as water organizations to focus on deficit irrigation practices for reducing water utilizations in agriculture.

The main target in deficit irrigation strategy is improving the water efficacy for obtaining higher crop production by unit applied water (Fereres and Soriano 2007, Yavuz et al. 2020, Yavuz et al. 2021). In such deficit irrigation, crops are exposed to the certain level of water stress conditions in whole or particular crop growing cycles (English and Raja 1996). In the literature reviews, water deficiency during the periods of flowering and pod filling is very critical for dry bean production in Mediterranean environments (Boutraa and Sanders 2001, Munoz-Perea et al. 2006, Ninou et al. 2013, Ucar et al. 2009). In those growing cycles, rainfall pattern is not uniform in Mediterranean region so in case of irrigation water stress has resulted drops in flowers and pods. On the other hand, crops are not equally sensitive to water stress in whole cycles of crop vegetation period. The sensitivities of crops to the water deficiency vary during the growing stages. In areas where water supplies are limited timing of water deficiency therefore is key issue for correct irrigation water management.
In the literature citations, information relevant to the $\mathrm{ET}_{\mathrm{a}}, \mathrm{K}_{\mathrm{c}}$, and $\mathrm{k}_{\mathrm{y}}$ as a function of growth cycles for different irrigation doses effect on dry bean response to yield is insufficient under growing environments of Turkey. Knowledge about $\mathrm{K}_{\mathrm{c}}$ and $\mathrm{K}_{\text {pan }}$, very important for irrigation program in regional basis is particularly almost none in some developing countries including Turkey.

The aims of the current study are as follows: (1) determination of the $\mathrm{ET}_{\mathrm{a}}$ values and seed yield for dry bean for different irrigation treatments; (2) developing the $\mathrm{K}_{\mathrm{c}}, \mathrm{K}_{\mathrm{pan}}$, and $\mathrm{k}_{\mathrm{y}}$ values from water using data for actual growing and regional climatic conditions to be used in irrigation scheduling and management at a regional scale.

\section{Materials and Methods}

\section{Experimental Area}

The study was performed at the research field belonging Faculty of Agricultural, University of Selcuk that is situated at Konya province having $38^{\circ} 58^{\prime} \mathrm{N}$ latitude, $32^{\circ} 06^{\prime} \mathrm{E}$ longitude, and $1006 \mathrm{~m}$ above sea level during the periods 2013-2014. The soil of experimental area is clay-loam (CL) with Entisol and is poor organic matter, the field capacity of $0.42 \mathrm{~m}^{3} \mathrm{~m}^{-3}$, and the permanent wilting point of $0.26 \mathrm{~m}^{3} \mathrm{~m}^{-3}$ as a consequent total usable water for the upper $0.6 \mathrm{~m}$ of the soil profile is around $96 \mathrm{~mm}$ (Table 1) as well as slope of site being less than $0.15 \%$.

Table 1

Some physical and chemical properties of the experimental site soil (The values are average for $0-60 \mathrm{~cm}$ soil depth)

\begin{tabular}{ll}
\hline Parameter & Value and unit \\
\hline Texture & Clay-loam \\
FC (field capacity) & $0.42 \mathrm{~m}^{3} \mathrm{~m}^{-3}$ \\
PWP (permanent wilting point) & $0.26 \mathrm{~m}^{3} \mathrm{~m}^{-3}$ \\
Zr (root zone depth) & $0.6 \mathrm{~m}$ \\
Mean bulk density & $1.3 \mathrm{~g} \mathrm{~cm}^{-3}$ \\
TAW (total available water) & $96 \mathrm{~mm}$ \\
RAW (readily available water) & $38.4 \mathrm{~mm}$ \\
P (soil water ET deficit factor) & 0.40 \\
pH & 7.74 \\
Organic Matter & $1.57 \%$ \\
\hline
\end{tabular}

The experimental site is typical semi-arid environment having dry or hot summers, and cold and snowy winters. In accordance of long-year climate records including 1960-2013, average annual precipitation is around $323 \mathrm{~mm}$ but, $25 \%$ of such rainfall has observed during the May-August in Konya plain. The prevailing wind orientation is NW to NNW. As seen in Table 2, climatic data during the vegetation period of 20132014 were in line with the historical average for the plain. 
Table 2

Variations of meteorological parameters of region during experimental years

\begin{tabular}{|c|c|c|c|c|c|c|c|c|}
\hline Months & & $\begin{array}{l}\text { Mean max. } \\
\text { temp. } \\
\left({ }^{\circ} \mathrm{C}\right)\end{array}$ & $\begin{array}{l}\text { Mean min. } \\
\text { temp. } \\
\left({ }^{\circ} \mathrm{C}\right)\end{array}$ & $\begin{array}{l}\text { Mean wind } \\
\text { speed } \\
\left(\mathrm{m} \mathrm{s}^{-1}\right)\end{array}$ & $\begin{array}{l}\text { Mean Rela- } \\
\text { tive humidity } \\
(\%)\end{array}$ & $\begin{array}{l}\text { Precipitation } \\
\quad(\mathrm{mm})\end{array}$ & $\begin{array}{l}\text { Mean solar } \\
\text { radiation } \\
\left(\mathrm{MJm}^{-2} \mathrm{day}^{-1}\right)\end{array}$ & $\begin{array}{l}\text { Mean daily } \\
\text { sunshine (h) }\end{array}$ \\
\hline \multirow[t]{3}{*}{ May } & $2013^{a}$ & 25.2 & 11.4 & 2.2 & 59.8 & 46.0 & 23.5 & 7.8 \\
\hline & $2014^{\mathrm{b}}$ & 24.9 & 8.6 & 2.0 & 56.4 & 6.4 & 24.3 & 8.5 \\
\hline & 53 years & 22.2 & 8.5 & 2.2 & 55.9 & 43.8 & 25.0 & 8.5 \\
\hline \multirow[t]{3}{*}{ June } & 2013 & 28.4 & 14.4 & 2.9 & 47.8 & 8.8 & 25.8 & 10.6 \\
\hline & 2014 & 26.4 & 12.5 & 2.6 & 55.9 & 55.6 & 24.9 & 9.3 \\
\hline & 53 years & 26.6 & 12.7 & 2.5 & 48.4 & 22.9 & 27.8 & 10.4 \\
\hline \multirow[t]{3}{*}{ July } & 2013 & 29.5 & 17.3 & 3.3 & 40.1 & 5.4 & 27.2 & 11.1 \\
\hline & 2014 & 32.0 & 16.7 & 3.2 & 44.3 & 9.6 & 27.7 & 11.3 \\
\hline & 53 years & 30.0 & 15.9 & 2.8 & 42.1 & 6.8 & 28.7 & 11.4 \\
\hline \multirow[t]{3}{*}{ August } & $2013^{c}$ & 30.5 & 17.2 & 2.9 & 38.6 & - & 26.6 & 11.0 \\
\hline & $2014^{\mathrm{d}}$ & 31.6 & 17.7 & 3.2 & 42.5 & 2.2 & 25.1 & 11.3 \\
\hline & 53 years & 29.9 & 15.4 & 2.6 & 42.9 & 5.5 & 26.6 & 11.1 \\
\hline Seasonal & 2013 & 28.4 & 15.1 & 2.8 & 46.6 & 60.2 & 25.8 & 10.1 \\
\hline average/ & 2014 & 28.7 & 13.9 & 2.8 & 49.8 & 73.8 & 25.5 & 10.1 \\
\hline total & 53 years & 27.2 & 13.1 & 2.5 & 47.3 & 79.0 & 27.0 & 10.4 \\
\hline
\end{tabular}

${ }^{\mathrm{b}}$ Calculated from the data between 16 and 31 May ${ }^{\mathrm{d}}$ Calculated from the data between 1 and 21 August

The meteorological data used in this study was obtained from the automatic meteorological station (Vantage Pro2, Davis Instruments, CA) mounted at the experimental site. Air temperature, precipitation, relative humidity, atmospheric air pressure, solar radiation, and wind speed at a height of $2 \mathrm{~m}$ were measured hourly by that station. Those data were controlled for reliability analysis as suggested by Allen et al. (1998).

Irrigation System

The trickle irrigation system was used for water application for crops. That system was installed through the experimental plots just before the crop growing season in both years. The lateral tubes were placed on each plant row with $0.5 \mathrm{~m}$ apart at space of almost 5-10 $\mathrm{cm}$ apart the plant stem. The laterals were in-line pressure regulating emitters producing discharge of $4 \mathrm{l} \mathrm{h}^{-1}$ for a pressure of $1 \mathrm{~kg} \mathrm{~cm}^{-2}$. The space between drippers was preferred as $0.40 \mathrm{~m}$ by considering properties of soil (Keller and Bliesner 1990). The target volume of irrigation water was measured by using water meters connected to the each plot. The irrigation water source was deep well having water table depth of around $30 \mathrm{~m}$ in experimental site.

\section{Irrigation Treatments}

The timing of irrigation within the critical crop cycles was considered in the experimental design. There were three cycles namely vegetative $(\mathrm{V})$, reproductive $(\mathrm{R})$, and pod filling-maturation $(\mathrm{P})$ were examined to determine irrigation scheduling. The reproductive stage began by the occurrence of floral buds and finished by full-length pods in bottom nodes (Doorenbos and Kassam 1979, Nielsen and Nelson 1998). The growing period was considered as about 14-week: 5-week vegetative period (from establishment to the occurrence of floral buds), 4-week reproductive period (from the occurrence of floral buds to the end of pod development), and 5-week pod filling and maturation period (from the end of pod development to harvest) in both experimental years. The details of the experimental treatments are presented in Table 3. The practice of full irrigation, $100 \% \mathrm{ET}$, in each of those stages was planned as VPR.

Table 3

Irrigation treatments applied in the study

\begin{tabular}{llll}
\hline \multirow{2}{*}{$\begin{array}{l}\text { Experimental } \\
\text { treatments }\end{array}$} & \multicolumn{3}{c}{ Growth stages } \\
\cline { 2 - 4 } & $\begin{array}{l}\text { Vegetative } \\
(\mathrm{V})\end{array}$ & $\begin{array}{l}\text { Reproductive } \\
(\mathrm{R})\end{array}$ & $\begin{array}{l}\text { Pod fill and } \\
\text { maturity (P) }\end{array}$ \\
\hline VRP & I & I & I \\
VR & I & I & 0 \\
VP & I & 0 & I \\
RP & 0 & I & I \\
V & I & 0 & 0 \\
R & 0 & I & 0 \\
P & 0 & 0 & I \\
Rain-fed & 0 & 0 & 0 \\
\hline
\end{tabular}

I, full irrigated at a given stage; 0 , irrigation omitted.

Vegetative growth period: 11 May-17 June (38-day) in 2013, and 16 May-20 June (36-day) in 2014.

Reproductive period: 18 June-13 July (26-day) in 2013, and 21 June18 July (28-day) in 2014.

Pod fill-maturation period: 14 July-18 August (36-day) in 2013, and 19 July- 21 August (34-day) in 2014.

Entire growth season: 100-day in 2013, and 98-day in 2014.

Irrigation was done only at certain growth cycles and ignored at other growth cycles till end of the targeted growth cycle in other treatments. Whole experimental plots were irrigated with the same as VPR treatment. Irrigation at all growth cycles was done by irrigation water needed to reach the $0-60 \mathrm{~cm}$ soil depth to the field capacity moisture level. Irrigation was started when around $40 \%$ of the total available was used at the top $0.60 \mathrm{~m}$ of the soil profile for the VPR treatment.

Agronomy

The current experiment was organized in a randomized block design with three replications. All plots had five rows with $5 \mathrm{~m}$ long and at a space of $50 \mathrm{~cm}$. Around $2.5 \mathrm{~m}$ spacing was left between plots to protect water entrance towards to plots. Dry bean seeds were sown manually on 11 May 2013 and 16 May 2014 with 
a density of 25 seeds per $\mathrm{m}^{2}$. As a basal fertilization, nitrogen and phosphorus were given and mixed through the soil by a disk harrow. The application doses were $80 \mathrm{~kg} \mathrm{~N} \mathrm{ha}^{-1}$ as $\left(\mathrm{NH}_{4}\right)_{2} \mathrm{SO}_{4}$ and $50 \mathrm{~kg} \mathrm{P}_{2} \mathrm{O}_{5}$ $\mathrm{ha}^{-1}$ as superphosphate. The crop was kept free of weeds by hand hoeing in case of needy. Beans were harvested when plants were physiologically matured on 18 Aug. 2013 and 21 Aug. 2014. However, the rain-fed and $\mathrm{V}$ treatments were harvested approximately 10 days earlier than other treatments in both the years because of differences in maturity resulting water stress.

\section{Measurements}

The soil water contents were monitored using a profile probe (model PR2, Delta-T, UK) at a depth of 0.2 $\mathrm{m}$ which increments to $1.0 \mathrm{~m}$ prior to and after irrigation from each plot during the growing season. In addition, the soil moisture content was recorded at sowing, at every 7-day frequency and at the time of harvest process. One access tube was placed in every treatment. The profile probe was calibrated in accordance of gravimetric soil analyses simultaneously with the probe readings at whole tubes across the experimental site before the application of first irrigation.

Following water budget equation as suggested by James (1988) was applied to calculate actual evapotranspiration $\left(\mathrm{ET}_{\mathrm{a}}\right)$ with constant 7-day duration for different irrigation levels:

$$
\mathrm{ET}_{\mathrm{a}}=I+P+C_{\mathrm{r}}-D_{\mathrm{p}}-R_{\mathrm{f}} \pm \Delta S \quad \ldots
$$

Where $\mathrm{I}$ is the applied by irrigation for individual parcels $(\mathrm{mm}), \mathrm{P}$ is the rainfall amount $(\mathrm{mm}), \mathrm{C}_{\mathrm{r}}$ is the capillary movement upward direction $(\mathrm{mm}), \mathrm{D}_{\mathrm{p}}$ is the amount of water by deep percolation $(\mathrm{mm}), \mathrm{R}_{\mathrm{f}}$ is the amount of runoff $(\mathrm{mm})$, and $\Delta \mathrm{S}$ is the variation in soil moisture status ( $\mathrm{mm}$ ). Rainfall as daily was recorded in the research site by a digital weather platform. $\mathrm{C}_{\mathrm{r}}$ was ignored due to the no upward water movement to the soil rooting systems in the experimental site. In this study, $R_{f}$ was assumed to be zero since there were ridges between the adjacent plots preventing run-off and run-on. $\Delta \mathrm{S}$ was determined by moisture monitoring in the soil profile having depth of $60 \mathrm{~cm}$. Amount of applied water for each treatment by irrigation was not higher than field capacity of soil so seepage as percolation was counted out.

Table 4

The seasonal amount of irrigation water $(\mathrm{I})$, precipitation $(\mathrm{P})$, actual evapotranspiration $\left(\mathrm{ET}_{\mathrm{a}}\right)$, and irrigation compensation $\left(I_{\mathrm{rc}}\right)$

\begin{tabular}{lcccccccc}
\hline \multirow{2}{*}{ Treatments } & \multicolumn{2}{c}{$\mathrm{I}(\mathrm{mm})$} & \multicolumn{2}{c}{$\mathrm{P}^{\mathrm{a}}(\mathrm{mm})$} & \multicolumn{2}{c}{$\mathrm{ET}_{\mathrm{a}}(\mathrm{mm})$} & \multicolumn{2}{c}{$I_{\mathrm{rc}}(\%)$} \\
\cline { 2 - 9 } & 2013 & 2014 & 2013 & 2014 & 2013 & 2014 & 2013 & 2014 \\
\hline VRP & 501 & 514 & 60.2 & 73.8 & 544 & 558 & 92 & 92 \\
VR & 312 & 320 & 54.8 & 69.2 & 414 & 430 & 75 & 74 \\
VP & 280 & 269 & 58.4 & 66.8 & 311 & 302 & 90 & 89 \\
RP & 354 & 348 & 6.2 & 11.8 & 391 & 387 & 91 & 90 \\
V & 102 & 115 & 54.0 & 62.0 & 199 & 221 & 51 & 52 \\
R & 228 & 241 & 0.8 & 7.2 & 331 & 350 & 69 & 69 \\
P & 162 & 169 & 5.4 & 4.6 & 184 & 195 & 88 & 87 \\
Rain-fed & - & - & - & - & 104 & 110 & - & - \\
\hline
\end{tabular}

\footnotetext{
${ }^{\mathrm{a}}$ Amount of precipitation in each growth period
} 
The amount irrigation water depended on irrigation treatments varying from 102 to $501 \mathrm{~mm}$ in 2013 and from 115 to $514 \mathrm{~mm}$ in 2014. The total irrigation water application for treatments was influenced by the amount and uniformity of the rainfall within the growing season. The highest applied irrigation water was found in the VRP treatments for both study years. However, the seasonal applied irrigation water in the V treatment was found minimum resulting from lower evaporative demand, mostly met from the rainfall at the beginning of the plant development. In result, the amounts of irrigation water for whole treatments were different due to variations in the soil moisture content and rainfall at a specific stage of the plant development period.

The seasonal $\mathrm{ET}_{\mathrm{a}}$ values were found between 104 and $544 \mathrm{~mm}$ in 2013 and between 110 and $558 \mathrm{~mm}$ for 2014 in whole growing time of 100 and 98 days, respectively. The maximum actual evapotranspiration was determined from VRP irrigation treatment for both the years. Some studies have demonstrated marginally less water uses of dry bean for a 90- to a 100-day season varying from 350 to $500 \mathrm{~mm}$ due to the differences in the soil, environment, and crop variety (Allen et al 2000). Calvache et al. (1997) stated a crop water consumption as $447 \mathrm{~mm}$ of dry bean having growing period of 122-day, while Munoz-Perea et al (2007) found crop water requirements of $318 \mathrm{~mm}$ of dry bean cultivar "NW 63" and $457 \mathrm{~mm}$ of cultivar of "Othello" at full-irrigation treatments in Kimberly, ID. Nielsen and Nelson (1998) added that ETa values are between 265 and $455 \mathrm{~mm}$ for black bean which was grown in conditions of eastern Colorado having $183 \mathrm{~mm}$ of irrigation water with no rainfall. In the current study, the relatively high seasonal crop water use values depend on many factors such as environment, water resources, soil, topography and so on.

In the current work, a large parts of evapotranspiration was supported by water application by irrigation. Irrigation compensation $\left(\mathrm{I}_{\mathrm{rc}}\right)$ ranged between 51 and $92 \%$ in 2013, and 52 and $92 \%$ in 2014. The $\mathrm{I}_{\mathrm{rc}}$ value of treatment irrigated at all growth periods was higher than those watered at the individual growth periods. As
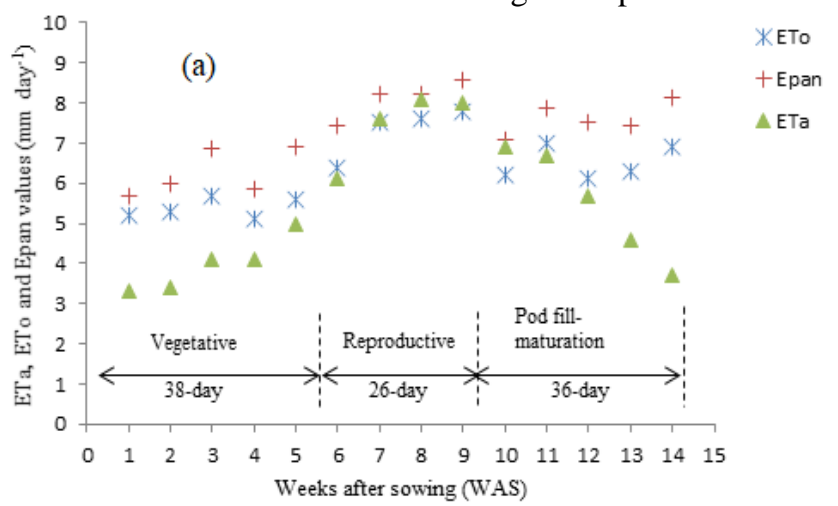

expected, well-watered plants consume greater water as it is more abundantly usable, so the plants do not experience the water deficiency. The proper irrigations control the great fluctuation in plant water stress resulted by insufficient watering (Radin et al. 1989). The fact that $82 \%$ of water use for pumpkin is contributed by irrigation in the Konya region as reported by Yavuz et al. (2015).

Relationship between $E T_{a}, E T_{0}, E T_{\text {pan }}$

ETa of the VRP, full irrigation, treatment determined by the soil water budget equation, ETo calculated using the FAO Penman-Monteith formula, and the Epan values obtained from Class-A Pan for the 2013 and 2014 growing seasons of dry bean are shown as means of one week in Figure 1, respectively. The values of ETa varied from 3.3 to $8.1 \mathrm{~mm} \mathrm{day}^{-1}$ during the growing season in 2013. It varied from 3.2 to $8.7 \mathrm{~mm}$ day $^{-1}$ in 2014. Those $\mathrm{ET}_{\mathrm{o}}$ values ranged from 5.1 to 7.8 $\mathrm{mm} \mathrm{day}{ }^{-1}$ in 2013 and from 4.8 to $8.1 \mathrm{~mm} \mathrm{day}^{-1}$ in 2014. The maximum $\mathrm{ET}_{\mathrm{a}}$ and $\mathrm{ET}_{\mathrm{o}}$ values were measured in the reproductive periods of dry bean in both years. The seasonal $\mathrm{ET}_{\mathrm{o}}$ value was found as $633.9 \mathrm{~mm}$ in 2013 and $654.0 \mathrm{~mm}$ in 2014. The $\mathrm{E}_{\mathrm{pan}}$ values for 2013 and 2014 varied from 5.7 to $8.6 \mathrm{~mm} \mathrm{day}^{-1}$ and from 5.2 to $9.3 \mathrm{~mm} \mathrm{day}^{-1}$, respectively. The seasonal $\mathrm{E}_{\mathrm{pan}}$ value was found as $724.2 \mathrm{~mm}$ in 2013 and 734.8 $\mathrm{mm}$ in 2014. The seasonal and weekly $\mathrm{E}_{\text {pan }}$ values were greater than the corresponding $\mathrm{ET}_{\mathrm{a}}$ and $\mathrm{ET}_{\mathrm{o}}$ values in both years because of climatic parameters such as high temperature and low humidity.

For estimation of the $K c$ values on a weekly basis, the real $\mathrm{ET}_{\mathrm{a}}$ values (VRP treatment) were divided to the corresponding $\mathrm{ET}_{\mathrm{o}}$ values. The highest $\mathrm{ET}_{\mathrm{a}}$ value as expected was obtained from the VRP treatment with enough water amount for crop water consumption. This value was decreased step by step for other irrigation treatments due to changes in the water use and evaporative requirement of the crop. Hence, the ETa ratio for the VRP treatment can be considered as the highest crop water use and thus it was used for calculation of the $K c$ values. The average values of crop coefficients in examined years were 0.75 for vegetative, 1.01 for

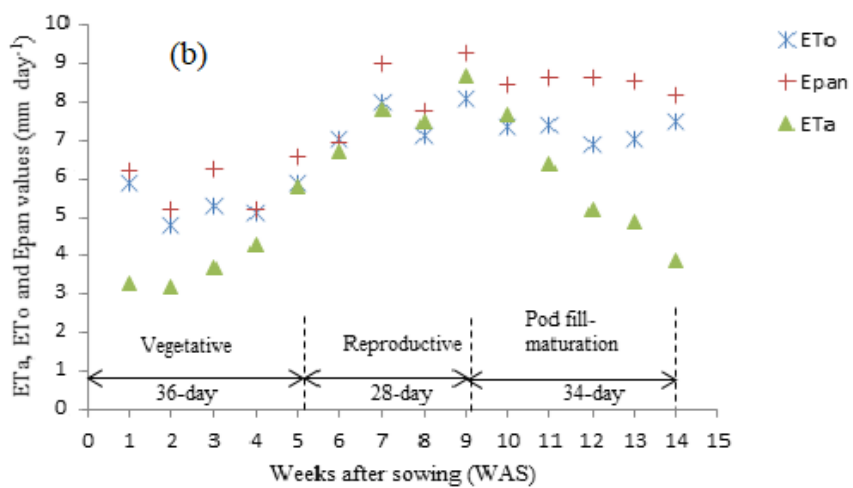

Figure 1

Time course evolution of $\mathrm{ET}_{\mathrm{o}}, \mathrm{E}_{\mathrm{pan}}$ and $\mathrm{ET}_{\mathrm{a}}$ during growing season $\quad(\mathrm{a}, 2013 ; \mathrm{b}, 2014)$ 
reproductive, and 0.82 for pod filling-maturation stages. The mean Kc was estimated as 0.85 for the all season (Table 5). The estimated Kc values almost conformity with the values reported by the FAO 56 for dry bean (Allen et al. 1998).
The values of $\mathrm{K}_{\mathrm{pan}}$ were computed from weekly $\mathrm{ET}_{\mathrm{o}}$ and $E_{p a n}$ values and were given in Table 5. In present work, $\mathrm{K}_{\mathrm{pan}}$ was between 0.85 and 0.92 during both crop growth periods. The seasonal $\mathrm{K}_{\text {pan }}$ values were 0.87 in 2013, 0.90 in 2014, and 0.89 in 2013-2014.

Table 5

Crop coefficients $\left(K_{\mathrm{c}}\right)$ and pan coefficients $\left(K_{\mathrm{pan}}\right)$ in both the growing season

\begin{tabular}{|c|c|c|c|c|c|c|}
\hline \multirow{2}{*}{ Growth stage } & \multicolumn{3}{|c|}{$K_{\mathrm{c}}$} & \multicolumn{3}{|c|}{$K_{\text {pan }}$} \\
\hline & 2013 & 2014 & Average & 2013 & 2014 & Average \\
\hline Vegetative & 0.74 & 0.75 & 0.75 & 0.86 & 0.92 & 0.89 \\
\hline Reproductive & 1.01 & 1.01 & 1.01 & 0.90 & 0.92 & 0.91 \\
\hline Pod fill-maturation & 0.85 & 0.78 & 0.82 & 0.85 & 0.85 & 0.85 \\
\hline Entire season & 0.86 & 0.83 & 0.85 & 0.87 & 0.90 & 0.89 \\
\hline
\end{tabular}

\section{Yield Parameters and Water Use Efficiency}

The analysis of variance showed that in exception of the 1000-seed weight, whole parameters insignificantly influenced by years (Table 6 ). The year $\times$ treatment interaction was also found not significant for all the parameters at $\mathrm{P}<0.05$ levels. Therefore, the results were assessed in combined years (2013 and 2014) considering the seed yield, yield components, WUE, and IWUE.

Average among years, the seed yield, yield components, and the WUE and IWUE findings are presented in Table 7. Timing of water stress on seed yield of dry bean was found significant $(\mathrm{P}<0.05)$. The maximum seed yield as average $2362.5 \mathrm{~kg} \mathrm{ha}^{-1}$ was determined from full-irrigated treatment during both the growing

Table 6

Mean squares from the variance analyses of the yield and yield components in combined years

\begin{tabular}{|c|c|c|c|c|c|c|c|}
\hline Source & d.f. $^{\text {a }}$ & Seed yield & Pods plant ${ }^{-1}$ & Seeds pod $^{-1}$ & 1000-seed weight & WUE & IWUE \\
\hline Blocks (B) & 2 & $4100.2^{\mathrm{ns}}$ & $0.25^{\mathrm{ns}}$ & $0.03^{\text {ns }}$ & $36.1^{\mathrm{ns}}$ & $0.001^{\mathrm{ns}}$ & $0.001^{\mathrm{ns}}$ \\
\hline Years (Y) & 1 & $57546.7^{\mathrm{ns}}$ & $0.10^{\mathrm{ns}}$ & $0.0004^{\mathrm{ns}}$ & $616.3^{*}$ & $0.0004^{\mathrm{ns}}$ & $0.0001^{\mathrm{ns}}$ \\
\hline Error 1 & 2 & 9526.5 & 0.23 & 0.051 & 17.5 & 0.002 & 0.003 \\
\hline Treatments $(\mathrm{T})$ & 7 & $3366463.8^{* *}$ & $42.3^{* *}$ & $1.83^{* *}$ & $5830.2^{* *}$ & $0.072^{* *}$ & $0.107^{* *}$ \\
\hline $\mathrm{Y} \times \mathrm{T}$ & 7 & $23882.1^{\mathrm{ns}}$ & $1.03^{\mathrm{ns}}$ & $0.025^{\mathrm{ns}}$ & $133.4^{\mathrm{ns}}$ & $0.002^{\mathrm{ns}}$ & $0.004^{\mathrm{ns}}$ \\
\hline$Y \times B$ & 2 & $9526.5^{\mathrm{ns}}$ & $0.23^{\mathrm{ns}}$ & $0.051^{\mathrm{ns}}$ & $17.5^{\mathrm{ns}}$ & $0.002^{\mathrm{ns}}$ & $0.003^{\mathrm{ns}}$ \\
\hline Error 2 & 28 & 18464.5 & 0.46 & 0.029 & $69.8^{\text {ns }}$ & 0.002 & 0.004 \\
\hline
\end{tabular}

${ }^{a}$ Degrees of freedom for combined over 2 years.

${ }^{n s}$ Non-significant.

Table 7

Seed yield, yield components, WUE and IWUE

\begin{tabular}{lccccccc}
\hline Treatments & $\begin{array}{c}\text { Seed yield } \\
\left(\mathrm{kg} \mathrm{ha}^{-1}\right)\end{array}$ & $\begin{array}{c}\text { Relative seed } \\
\text { yield }(\%)\end{array}$ & $\begin{array}{c}\text { Pods plant } \\
1\end{array}$ & $\begin{array}{c}\text { Seeds } \\
\mathrm{pod}^{-1}\end{array}$ & $\begin{array}{c}1000-\mathrm{seed} \\
\text { weight }(\mathrm{g})\end{array}$ & $\begin{array}{c}\text { WUE } \\
\mathrm{kg} \mathrm{m}^{-3}\end{array}$ & $\begin{array}{c}\text { IWUE } \\
\mathrm{kg} \mathrm{m}^{-3}\end{array}$ \\
\hline$V R P$ & $2362.5 \mathrm{a}$ & 100.0 & $11.7 \mathrm{a}$ & $3.2 \mathrm{a}$ & $334.8 \mathrm{a}$ & $0.43 \mathrm{a}$ & $0.44 \mathrm{~b}$ \\
$V R$ & $1884.8 \mathrm{~b}$ & 79.8 & $11.7 \mathrm{a}$ & $2.8 \mathrm{~b}$ & $302.7 \mathrm{~b}$ & $0.45 \mathrm{a}$ & $0.56 \mathrm{a}$ \\
$V P$ & $884.9 \mathrm{e}$ & 37.5 & $7.9 \mathrm{c}$ & $2.5 \mathrm{~cd}$ & $286.7 \mathrm{c}$ & $0.29 \mathrm{~cd}$ & $0.28 \mathrm{c}$ \\
$R P$ & $1552.8 \mathrm{c}$ & 65.7 & $9.9 \mathrm{~b}$ & $2.7 \mathrm{bc}$ & $334.4 \mathrm{a}$ & $0.40 \mathrm{ab}$ & $0.41 \mathrm{~b}$ \\
$V$ & $737.1 \mathrm{e}$ & 31.2 & $8.5 \mathrm{c}$ & $2.0 \mathrm{e}$ & $264.4 \mathrm{~d}$ & $0.35 \mathrm{bc}$ & $0.57 \mathrm{a}$ \\
$R$ & $1213.6 \mathrm{~d}$ & 51.4 & $10.6 \mathrm{~b}$ & $2.4 \mathrm{~d}$ & $283.2 \mathrm{c}$ & $0.36 \mathrm{bc}$ & $0.46 \mathrm{ab}$ \\
$P$ & $475.3 \mathrm{f}$ & 20.1 & $6.3 \mathrm{~d}$ & $1.8 \mathrm{ef}$ & $279.3 \mathrm{c}$ & $0.25 \mathrm{~d}$ & $0.21 \mathrm{c}$ \\
Rain-fed & $122.9 \mathrm{~g}$ & 5.2 & $4.2 \mathrm{e}$ & $1.6 \mathrm{f}$ & $246.9 \mathrm{e}$ & $0.11 \mathrm{e}$ & - \\
Average & 1154.2 & - & 8.8 & 2.4 & 291.5 & 0.33 & 0.42 \\
Cv(\%) & 11.8 & - & 7.7 & 7.2 & 2.9 & 13.5 & 15.1 \\
\hline
\end{tabular}

seasons. Water deficiency through different growing period resulted variations in seed yields obtained in other treatments.

The treatments introducing irrigation water at only one phonological cycle led to significantly different seed yield values in both years. Averaged over the years, the highest seed yield as $1213.6 \mathrm{~kg} \mathrm{ha}^{-1}$ was found at irrigation water applied only at the reproductive cycle, whereas the minimum seed yield as 475.3 $\mathrm{kg} \mathrm{ha}^{-1}$ was determined for irrigation water applied only at the pod filling-maturation cycle. The P treatment showed a significant reduction $(-80 \%)$ in the seed yield by comparison to full irrigation during whole the growing period.

${ }^{*}$ Significant at the $1 \%$ of probability level $(\mathrm{P}<0.01)$

* Significant at the $5 \%$ of probability level $(\mathrm{P}<0.05)$. 
In the treatments involving irrigation during two phonological stages, the relatively high seed yields were obtained from the VR treatment counting on the ignorance of irrigation at the pod filling-maturation cycle in both years. This finding indicated the relative resistance of dry bean to soil water deficiency at the pod filling-maturation stage and is generally conformity with the results obtained by Nielsen and Nelson (1998) who experimented on black bean. However, the ignoring of irrigation only during the reproductive stage (VP treatment) resulted much less values of the seed yield than those obtained with the RP treatment (water ignorance during the vegetative stage) and the VR treatment (water omission during the pod fillingmaturation) (Figure 2). The VP irrigation treatment (water omission during the reproductive stage) reduced the seed yield by about $63 \%$ by comparison to VPR treatment (full irrigation) (Table 7).

The periods of water stress during the reproductive period of the dry bean led to significant losses in the seed yield (Boutraa and Sanders 2001, Munoz-Perea et al. 2006, Nielsen and Nelson 1998, Pimentel et al. 1999, Ramirez-Vallejo and Kelly 1998).
The irrigation treatments had significant effect on yield components of dry bean such as number of pods per plant, number of seeds per pod, and 1000-seed weight $(\mathrm{P}<0.05)$. The number of pods per plant ranged between 11.7 (VPR and VR treatments) and 4.2 (rainfed treatment). The maximum numbers of seeds in pod were obtained ( 3.2 seeds per pod) in the VPR treatment followed by the VR (2.8 seeds per pod) and RP (2.7 seeds per pod) treatments. The lowest numbers of seeds per pod (1.6 seeds pod $\left.^{-1}\right)$ were observed when water stress was available at all growth periods (rain-fed treatment) and the vegetative + reproductive stages $(\mathrm{P}$ treatment). Water stress (especially water stress at the reproductive cycle) interferes with pollination and results in an increased number of barren plants and incomplete seed setting (Teran and Singh 2002).

The VRP and RP treatments produced the maximum 1000-seed weights (no statistical difference), while the minimum 1000-seed weights were found at rain-fed treatment. In general, full irrigation (VRP) showed a greater efficacy than other treatments with respect to yield components.

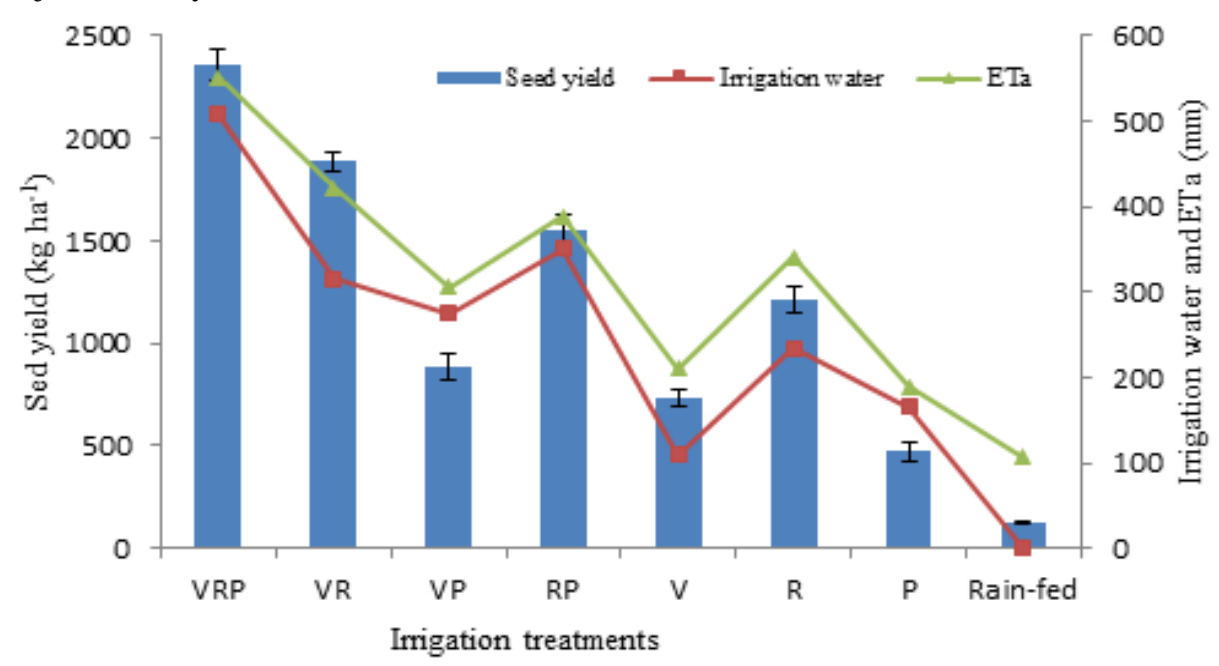

Figure 2

Seed yield, seasonal amount of irrigation water and ET $\mathrm{a}$ in combined years (2013 and 2014) (Error bars represent the standard error values).

In this study, the WUE was higher in the VR treatment as $0.45 \mathrm{~kg} \mathrm{~m}^{-3}$ followed by the VRP treatment as $0.43 \mathrm{~kg} \mathrm{~m}^{-3}$ and the RP treatment as $0.40 \mathrm{~kg} \mathrm{~m}^{-3}$. On the other hand, difference in the WUE value between these three treatments was not found statistically significant $(\mathrm{P} \leq 0.05)$. The lower values of the WUE were obtained for the treatments involving the ignorance of irrigation at the reproductive cycle. The WUE values demonstrated between 0.3 and $0.6 \mathrm{~kg} \mathrm{~m}^{-3}$ by Doorenbos and Kassam (1979) and Mahlooji et al. (2000). Accordingly, our study maintained the WUE values in the common boundary as stated for dry bean by those researchers. Similarly, Miller et al (2002) cited a mean WUE of 0.29 , varying between 0.03 and $0.67 \mathrm{~kg} \mathrm{~m}^{-3}$, for dry bean among regions and years at the Northern Great Plains of the USA. The WUE depends on the plant growth cycle influenced by water deficiency level. For dry bean, the minimum WUE was addressed when water stress occurrance at the flowering and pod setting cycles (Calvache et al. 1997, Libardi et al. 1999, Pimentel et al. 1999).

On the other hand, the deficit irrigation strategies highly increased IWUE (Table 7). The highest IWUE values were obtained in $\mathrm{V}$ as $0.57 \mathrm{~kg} \mathrm{~m}^{-3}$, VR as 0.56 $\mathrm{kg} \mathrm{m}^{-3}$, and $\mathrm{R}$ as $0.46 \mathrm{~kg} \mathrm{~m}^{-3}$ treatments and difference between these treatments was found no statistically significant in accordance of Duncan's multiple range tests. This result indicates the importance of both the vegetative and reproductive cycles in the programing of processing dry bean irrigation.

Yield Response Factor $\left(k_{y}\right)$

Average across both years, $k y$ values were calculated for all growing period and individual growth periods 
(Fig. 3). The seasonal ky value as known an important indicator in both irrigation and water deficit studies was estimated as an average of 1.19. Our seasonal $k y$ value in line with the findings of Doorenbos and Kassam (1979) $(k y=1.15)$ and Sezen et al (2005) $(k y=$ 1.23). The value of $k y$ shows the crop sensitivity status of crops for the water stress environments i.e. lower than 1.00 generally means that the crop is tolerant to water deficit in the soil (Doorenbos and Kassam 1979). In accordance of $k y$ value as 1.19 estimated from the current study, dry bean crop is sensitive to the water deficiency in soil. Many authors also reported that dry bean may strongly respond to water deficit (MunozPerea et al. 2006, Nunez-Barrios et al. 2005, Teran and Singh 2002, White et al. 1994, Ucar et al. 2009).

Except the VR treatment with $k y=0.87$ in which irrigation water was not applied only at the pod filling- maturation stage, for all growth periods the $k y$ value was greater than 1.00 (Fig. 3). Therefore, the bean plants could be considered as sensitive to water deficit in the vegetative and reproductive stages and tolerant to water stress condition in the pod filling-maturation period. In agreement with our findings, other researchers have also reported findings that such crop is more sensitive to water stress at the vegetative and flowering cycles (Efetha et al 2011, Munoz-Perea et al 2006, Nielsen and Nelson 1998). The maximum $k y$ value was obtained in the VP treatment as $k y=1.41$ in which water was not practiced only at the timing of reproductive. The common bean cultivars respond differently to water stress in the soil during the reproductive period depending on the magnitude of the water stress (Karamanos and Papatheohari 1999, Schneider et al 1997, Teran and Singh 2002).

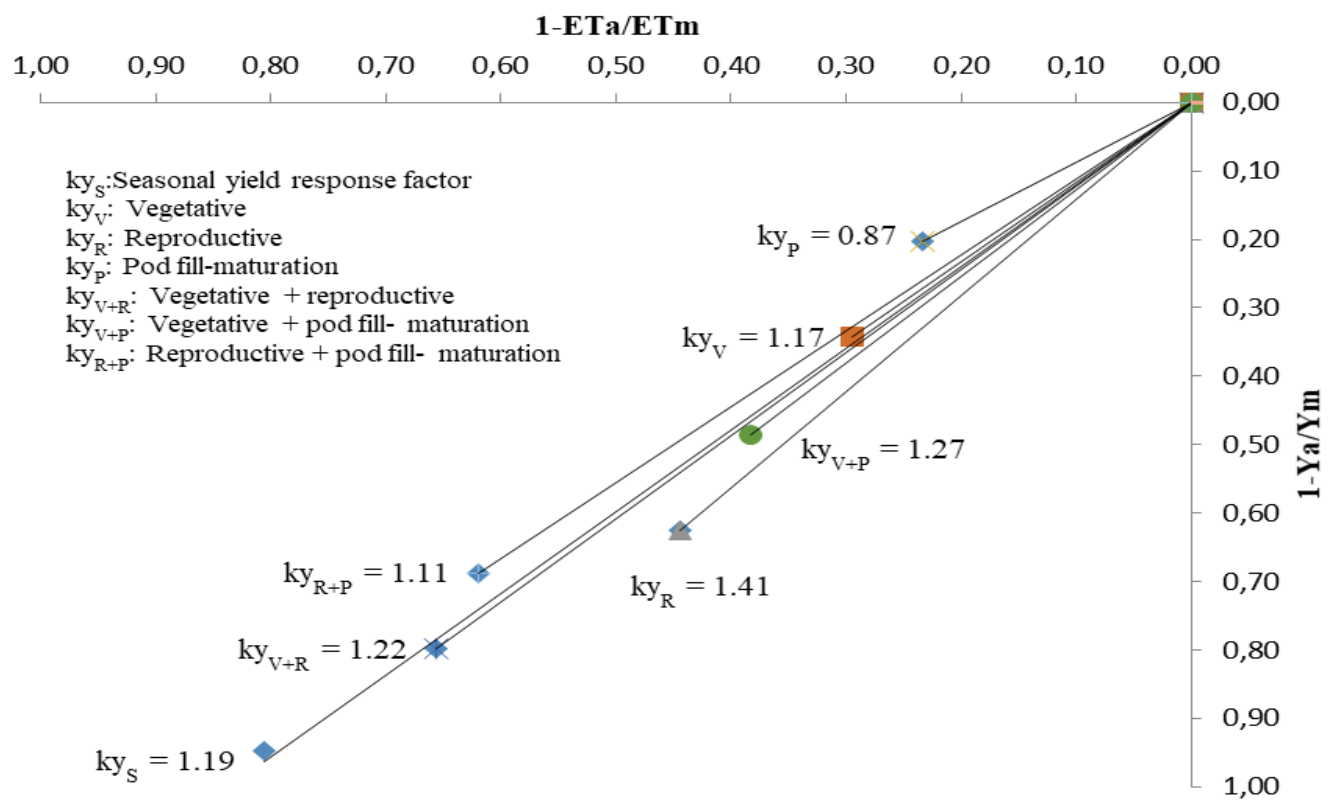

Figure 3

Yield response factors at various phonological stages of dry bean (in combined years)

\section{Conclusions}

In accordance of findings of two-year research, the maximum seed yield of $2362 \mathrm{~kg} \mathrm{ha}^{-1}$ was obtained from well-watered treatment (VPR) across the years. Seed yield of dry bean was affected significantly from water stress timing $(\mathrm{P}<0.05)$. The data in the current work showed that reproductive period of dry bean was found the most sensitive time to water stress. Water deficiency at the reproductive cycle resulted low seed yield of dry bean approximately by $63 \%$ reduction by comparison to full-watered treatment. The finding explicitly indicated the resistance of dry bean to soil water deficiency at the pod filling-maturation stage when analyzed considering the seed yield, yield components, WUE, IWUE, and $k y$.

Proper information relevant to $K c$, needed for irrigation management for regional scale, is unfortunately insufficient for many plants including dry bean in developing countries. Averaged over the years, for the vegetative, reproductive, and pod filling-maturation stages, the values of $K c$ were $0.75,1.01$, and 0.82 , respectively. The mean $K c$ was estimated to be 0.85 for the whole season. Across both the years, the seasonal $\mathrm{K}_{\mathrm{pan}}$ value was obtained as 0.89 during the growing season of dry bean. These values can be used in works relevant irrigation water management in arid and semiarid environments where water resources are is scant.

As a conclusion, full irrigation treatment (VRP) is suggested for dry bean to achieve greater seed yields. On the other hand, in water shortage environments such as Konya region, practicing full irrigation up to the beginning of the pod filling-maturation cycle and stopping irrigation from that point up to harvest as an alternative to full irrigation at the all growing period resulted an economical seed yield. Based on the results of the current work, irrigation water saving of $38 \%$ and 
an increment of $27 \%$ in IWUE, by comparison to full irrigation, could be accomplished with this irrigation treatment. The ignorance of irrigation during the vegetative and especially the reproductive cycles is not desirable for an economical production of dry bean.

\section{Acknowledgements}

The author would like to thank Associate Professor Dr. Duran Yavuz and Assistant Professor Dr. Sinan Süheri for their contributions to this study.

\section{References}

Allen RG, Pereira LS, Raes D, Smith M (1998). Crop evapotranspiration: Guidelines for computing crop water requirements. Irrigation and Drainage, $\mathrm{Pa}$ per No. 56, FAO, Rome, Italy, 300 pp.

Allen RG, Walter IA, Elliot RL, Howell TA, Itenfisu D, Jensen ME, Snyder RL (2005). The ASCE standardized reference evapotranspiration equation. American Society of Civil Engineering, Reston, VA, p.192.

Allen RG, Yonts CD, Wright JL (2000). Irrigation to maximize bean production and water use efficiency. In: Singh, S.P. (Ed), Bean Research, Production, and Utilization. Proc Idaho Bean Workshop. University of Idaho, Moscow, pp 71-92.

Boutraa T, Sanders FE (2001). Influence of water stress on grain yield and vegetative growth of two cultivars of bean (Phaseolus vulgaris L.). Journal of Agronomy and Crop Science 187: 251-257.

Calvache M, Reichardi K, Bacchi O, Dourado-Neto D (1997). Deficit irrigation at different growth stages of the common bean (Phaseolus vulgaris L., cv. Imbabello). Scientia Agricola 54(Special):1-16.

Deng XP, Shan L, Zhang H, Tuner NC (2006). Improving agricultural water use efficiency in arid and semiarid areas of China. Agricultural Water Management 80: 23-40.

Doorenbos J, Kassam AH (1979). Yield response to water. FAO Irrigation and Drainage Paper, No. 33. Food and Agriculture Organization of the United Nations, Rome, 193 pp.

Efetha A, Harms T, Bandara M (2011). Irrigation management practices for maximizing seed yield and water use efficiency of Othello dry bean (Phaseolus vulgaris L.) in southern Alberta, Canada. Irrigation Science 29: 103-113.

English M, Raja SN (1996). Perspectives on deficit irrigation. Agricultural Water Management 32: 114.

Er-Raki S, Chehbouni A, Boulet G, Williams DG (2010). Using the dual approach of FAO-56 for partitioning ET into soil and plant components for olive orchards in a semi-arid region. Agricultural Water Management 97: 1769-1778.
FAO (2020). Agriculture Production. See also: http://www.faostat.fao.org/faostat; (accessed 03.08.2020).

Fereres E, Soriano MA (2007). Deficit irrigation for reducing agricultural water use. Special issue on "integrated approaches to sustain and improve plant production under drought stress". Journal of Experimental Botany 58: 147-159.

Fernandez JE, Slawinski C, Moreno F, Walczak RT, Vanclooster M (2002). Simulating the fate of water in a soil-crop system of a semi-arid Mediterranean area with the WAVE 2.1 and the EURO-ACCESSII models. Agricultural Water Management 56, 113-129.

Ferreira TC, Carr MKV (2002). Responses of Potatoes (Solanum tuberosum L.) to Irrigation and Nitrogen in a Hot, Dry Climate. Field Crops Research 78: 51-64.

Grismer ME, Orang M, SnyderR, Matyac R (2002). Pan evaporation to reference evapotranspiration conversion methods. Journal of Irrigation and Drainage Engineering 128:180-184.

Howell TA, Cuenca RH, Solomon KH (1990). In: Hoffman, et al. (Eds.), Crop yield response. Manage of Farm Irrigation Systems. ASAE, 312 pp.

Irmak S, Haman DZ, Jones JW (2002). Evaluation of Class A pan coefficients for estimating reference evapotranspiration in humid location. J. Irrig. Drain. Eng. 128, 153-159.

James LG (1988). Principles of farm irrigation system design. Wiley, New York, 543 pp.

Kang SZ, Gu BJ, Du TS, Zhang JH (2003). Crop coefficient and ratio of transpiration to evapotranspiration of winter wheat and maize in a semi-humid region. Agricultural Water Management 59: 239254.

Karamanos AJ, Papatheohari AY (1999). Assessment of drought resistance of crop cultivars and lines by means of the water potential index. Crop Science 39: 1792-1797.

Keller J, Bliesner RD (1990). Sprinkle and Trickle Irrigation. Chapman and Hall, 115 Fifth Avenue, New York, NY 10003, USA, pp. 652.

Libardi PL, Moraes SO, Saad AM, Lier Q, Vieira O, Tuon RL (1999). Nuclear techniques to evaluate water use of field crops irrigated in different growth stages. In: Kirda, C., Moutonnet, P., Hera, C., Nielsen, D.R., (eds) Crop yield response to deficit irrigation. Kluwer, Dordrecht, pp 109-120.

Mahlooji M, Mousavi SF, Karimi M (2000). The effects of water stress and planting date on yield and yield components of pinto bean (Phaseolus vulgaris). Journal of Science and Technology of Agriculture Natural Resources 4: 57-68.

Miller PR, McConkey BG, Clayton GW, Brandt SA, Staricka JA, Johnston AM, Lafond GP, Schatz BG, Baltensperger DD, Neill KE (2002). Pulse crop ad- 
aptation in the northern Great Plains. Agronamy Journal 94: 261-272.

Munoz-Perea CG, Allen RG, Westermann DT, Wright JL, Singh SP (2007). Water use efficiency among dry bean landraces and cultivars in drought-stressed and non-stressed environments. Euphytica 155: 393-402.

Munoz-Perea CG, Teran H, Allen RG, Wright JL, Westermann DT, Singh SP (2006). Selection for drought resistance in dry bean landraces and cultivars. Crop Science 46: 2111-2120.

Nielsen DC, Nelson N (1998). Black bean sensitivity to water stress at various growth stages. Crop Science 38: 422-427.

Ninou E, Tsialtas JT, Dordas CA, Papakosta DK (2013). Effect of irrigation on the relationships between leaf gas exchange related traits and yield in dwarf dry bean grown under Mediterranean conditions. Agricultural Water Management 116: 235241.

Nunez-Barrios A, Hoogenboom G, Nesmith DS (2005). Drought stress and the distribution of vegetative and reproductive traits of a bean cultivar. Scientia Agricola 62: 18-22.

Pimentel C, Laffray D, Louguet P (1999). Intrinsic water use efficiency at the pollination stage as a parameter for drought tolerance in Phaseolus vulgaris. Physiologia Plantarum 106: 184-189.

Radin JW, Mauney JR, Kerridge PC (1989). Water uptake by cotton roots during fruit filling in relation to irrigation frequency. Crop Science 29: 10001005.

Ramirez-Vallejo P, Kelly J (1998). Traits related to drought resistance in common bean. Euphytica 99: 127-136.

Schneider KA, Brothers ME, Kelly JD (1997). Marker assisted selection to improve drought resistance in common bean. Crop Science 37: 51-60.

Sezen MS, Yazar A, Canbolat M, Eker S, Celikel G (2005). Effect of drip irrigation management on yield and quality of field grown green beans. Agricultural Water Management 71: 243-255.
Snyder RL, Orang M, Matyac S, Grismer ME (2005). Simplified estimation of reference evapotranspiration from pan evaporation data in California. Journal of Irrigation and Drainage Engineering 131: 249-253.

Teran H, Singh SP (2002). Comparison of sources and lines selected for drought resistance in common bean. Crop Science 42: 64-70.

TUIK (2020). Turkish Statistical Institute. See also: http://www.tuik.gov.tr; (accessed 14.11.2020).

Ucar Y, Kadayifci A, Yilmaz HI, Tuylu GI, Yardimci $N$ (2009). The effect of deficit irrigation on grain yield of dry bean (Phaseolus vulgaris L.) in semiarid regions. Spanish Journal of Agricultural Research 7: 474-485.

White JW, Castillo JA, Ehleringer JR, Garcia-C JA, Singh SP (1994). Relations of carbon isotope discrimination and other physiological traits to yield in common bean (Phaseolus vulgaris) under rainfed conditions. Journal of Agricultural Science 122: 275-284.

Yavuz D, Yavuz N, Seymen M, Türkmen Ö (2015). Evapotranspiration, crop coefficient and seed yield of drip irrigated pumpkin under semi-arid conditions. Scientia Horticulture 197: 33-40.

Yavuz D, Seymen M, Süheri S, Yavuz N, Türkmen Ö, \& Kurtar ES (2020). How do rootstocks of citron watermelon (Citrullus lanatus var. citroides) affect the yield and quality of watermelon under deficit irrigation? Agricultural Water Management 241: 106351.

Yavuz D, Seymen M, Yavuz N, Çoklar H \& Ercan M (2021). Effects of water stress applied at various phenological stages on yield, quality, and water use efficiency of melon. Agricultural Water Management 246: 106673

Zhou WB (2003). Review on the study of water resources utilization efficiency in irrigation district in arid and semiarid areas of China. Journal of Arid Land Resources and Environment 17: 91-95. 